\title{
Optimized forest planning: allocation of log storage yards in the Amazonian sustainable forest management area
}

\author{
Evandro Ferreira da Silva ${ }^{\mathrm{a}, *}$, Gilson Fernandes da Silva ${ }^{\mathrm{b}}$, Evandro Orfanó Figueiredo ${ }^{\mathrm{c}}$, \\ Adriano Ribeiro de Mendonça ${ }^{\mathrm{b}}$, Cesar Junio de Oliveira Santana ${ }^{\mathrm{d}}$, Nilton César Fiedler ${ }^{\mathrm{b}}$, \\ Jeferson Pereira Martins Silva ${ }^{\mathrm{b}}$, Marcelo Otone Aguiar ${ }^{\mathrm{b}}$, Jeangelis Silva Santos ${ }^{\mathrm{b}}$ \\ ${ }^{\text {a }}$ Federal University of Piauí (UFPI), Campus Professora Cinobelina Elvas, Planalto Horizonte, 64900-000, Bom Jesus, PI, Brazil \\ ${ }^{\mathrm{b}}$ Federal University of Espírito Santo (UFES), Forest Sciences Post-graduate program. Av. Governador Lindemberg, Centro, 29550-000, Jerônimo Monteiro, ES, Brazil \\ ${ }^{\mathrm{c}}$ Brazilian Agricultural Research Corporation (EMBRAPA-Acre), Rodovia BR-364, km 14, 69900-970, Rio Branco, AC, Brazil \\ ${ }^{\mathrm{d}}$ Remsoft Solutions, Jose Alexandre Buaiz, 300, Sala $200110 \mathrm{Vg}$, Enseada do Sua, 29050-545, Vitoria, ES, Brazil
}

\section{A R T I C L E I N F O}

\section{Keywords:}

Operational Research

Precision Forest Management

Forest Concession

Productivity

\begin{abstract}
A B S T R A C T
In Amazonian native forest management, forest road infrastructures, such as log storage yards and skid trails, are the most expensive attributes and are responsible for the significant environmental impacts with selective tree felling. Road optimization is crucial for reducing environmental impacts and production costs and is strongly linked to the optimal location of storage yards, which are essential to forest road planning. Considering the present problem and the current solutions available, this case study aimed to evaluate the efficiency and eventual gains of optimized forest planning (OFP), as compared to traditional forest planning (TFP). The TFP method is currently used most frequently by forest companies in the Amazon region. The study area of 126.41 ha belongs to the National Forest (NAFO) Saracá-Taquera, Forest Management Unit II (FMU-II), Annual Production Unit (APU) 04/2018, and Work Unit (WU) 2. For the analysis, two areas were defined for exploration: the first was explored using the OFP mathematical model (57.75 ha) and the second followed the TFP plan of the company (68.66 ha). Plans and executions for both areas were compared. The OFP model significantly reduced the Euclidean distances between tree and yards, with only $0.23 \mathrm{~km}$ difference in the amount of planned forest

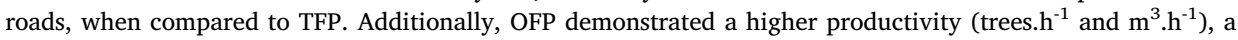
reduction of skid distance (by an average of $17.16 \%$ ), and reduced the cost of log skidding ( $\mathrm{m}^{3}$ by $25.76 \%$ ). Thus, this study proved that OFP is a viable solution that can be adopted by companies to increase productivity.
\end{abstract}

\section{Introduction}

Tropical wood production in the Amazon rainforest is one of the primary economic activities developed in this region and management of forest resources is a complex challenge. Thus, techniques used to manage forest resources should provide viable utilization techniques from the economic, environmental, and social perspective (Amaral et al., 1998), in addition to promoting ecosystem maintenance (Braz, 2010).

One of the main tools for sustainable use of forests is sustainable forest management (SFM). SFM aims to apply forest management and reduce the impact of logging techniques in ways that are appropriate to ensuring sustainable use of forest resources during selective logging of commercial trees. Exploration techniques and management information are described and presented in the sustainable forest management plan (SFMP), which is submitted to a responsible agency. It is necessary to follow the annual operating plan (AOP) to execute the exploration techniques. The AOP guides all activities performed in the forest management unit (FMU) (Brasil, 2009, 2006; IBAMA, 2007).

Selective logging is intended to only remove trees of commercial value. Its use is associated with forest management techniques and is referenced in the current legislation (Implementing rule no. 1, of April 24, 2007, of the Brazilian Institute of Environment and Water Resources), which defines cutting intensity in volume by area and by

\footnotetext{
* Corresponding author.

E-mail addresses: evandroflorestal@gmail.com (E. Ferreira da Silva), fernandes5012@gmail.com (G. Fernandes da Silva), evandro.figueiredo@embrapa.br (E. Orfanó Figueiredo), adriano.mendonca@ufes.br (A. Ribeiro de Mendonça), cesar.santana@remsoft.com (C. Junio de Oliveira Santana), nilton.fiedler@ufes.br (N. César Fiedler), jefersonsb09@hotmail.com (J. Pereira Martins Silva), marcelootone@gmail.com (M. Otone Aguiar), jeangelis@gmail.com (J. Silva Santos).
} 
species, in addition to providing a low impact exploration and execution planning (IBAMA, 2007). This planning considers the location of trees that will be logged, and necessary infrastructure, such as forest roads, logging yards, and logging trails for the development of activities.

In this context, AOP should consider the relationships between skid trails logs, storage yards, and forest roads, to minimize environmental impacts on the forest and maximize the economic performance of timber production. However, this is a complex problem (Philippart et al., 2012) because, among other reasons, the relationships between skid trails, storage yards, and forest roads are not yet well defined. In addition, such problems are influenced by economic, environmental, operational, and/or legal variables among others, which make them difficult to manage.

Therefore, to address such problems, researchers used operational research methods. Several examples of this method can be found in existing studies on the planning of forest production operations (Contreras and Chung, 2007; Karlsson et al., 2004; Murray and Snyder, 2000; Shahi and Pulkki, 2013; Søvde et al., 2013) but also related to issues of traditional communities, non-timber forest products and forest fragmentation (Arima et al., 2008, 2005; Braz et al., 2004; Kelley et al., 2013; Lopes, 2018; Munaretti, 2016; Walker et al., 2013). More specifically, Silva et al. (2018a) presented a theoretical study that discussed the relationship between forest road infrastructures, storage yards, and skid trails, and reported the need for more detailed analysis to be planned. There is a direct relationship between the increase in the number or storage yards and both skid trails reduction and the increase in development of forest roads. However, the optimal point of these relationships is still being explored. Studies on this issue are still being developed, as researchers try to determine a balance that optimizes the environmental, technical, legal, social, and economic characteristics.

However, the study presented by Silva et al. (2018a) did not present economic performance measures, nor model validation. Thus, although the model used by the authors proved to be feasible, its application in a real situation, with a survey of production process costs, would satisfy fundamental answers for the development of the referred model. In addition to Silva et al. (2018a), Braz and D'Oliveira, 1997, Machado, 2013, Sist (2000) e Bramucci and Seixas (2002) highlight the need to invest more in forest exploitation planning, as well as the need for further studies to increase operations productivity and consequently increase the economic performance of wood production activity.

It is very important to contextualize that timber production in the Amazon region through SFMP normally does not adopt any optimized system of infrastructure planning as proposed by Silva et al. (2018a). Decisions are usually made empirically, based on the decision maker's experience, and ignoring much of the complexity of the problem. Thus, although this has not been demonstrated, it is anticipated that the use of operational research techniques, with reliable data sources and knowledge of the production process, can significantly increase the performance of empirical methods currently employed (Gomide et al., 2011; Issac Júnior et al., 2014; Martinhago, 2012; Silva et al., 2018b).

Considering the present problem and current solutions available, this case study aims to evaluate the efficiency and eventual gains of optimized planning execution of storage yards allocation, in comparison with traditional planning execution currently used by most forest companies in the Amazon region.

\section{Materials and methods}

\subsection{Methodological Steps}

A methodological flowchart that represents the necessary steps for research development is presented in Figure 1. The central idea is the comparison of two types of planning for SFM infrastructure. To facilitate the presentation of methodology descriptions and results, herein we refer to the forest planning traditionally adopted by companies as traditional forest planning (TFP), and model proposed by this study as optimized forest planning (OFP).

Referring to the methodological flowchart, the details of items 1, 2, and 3 are presented below.

\subsection{Flowchart Item 1: study area description}

The study area was located at geographic coordinates $1^{\circ} 45^{\prime} 23$ " S and $56^{\circ} 34^{\prime} 21$ " W, Datum WGS 1984, known as FMU-1A. It has an area of 26,897.96 ha, located in municipalities Terra Santa and Oriximiná, Pará, and belongs to the Nacional Forest Saracá-Taquera (NAFO). FMU$1 \mathrm{~A}$ was legally granted to company EBATA Forest Products, through forest concession instrument, competition $\mathrm{N}^{\circ} 02 / 2012$, promoted by Brazilian Forest Service (BFS), pursuant to Law $n^{\circ} 11.284 / 2006$ and Decree $n^{\circ} 6,063 / 2007$, and holds Forest Stewardship Council (FSC ${ }^{\circledast}$ ) certification. The study area was located in Annual Production Unit (APU) 04/2018, Work Unit (WU)-2. The WU-2 has an area of 355.55 ha, of which 126.41 ha were analyzed in this study.

Native Amazonian forest is characterized by species heterogeneity and spatial distribution. Therefore, to minimize the differences between the two areas studied, contiguous areas were defined, with the greatest possible resemblance in relation to flat relief, forest typology, amount of trees to be logged, wood volume per area, total sum of tree-yard distances (according to traditional planning), and number of yards to be allocated. In the first area, exploration was conducted according to TFP. In the second area, exploration was conducted according to OFP (Figure 2).

Both TFP and OFP were based on information from the census forest inventory traditionally carried out by the company (Table 1 ). The methodology of the inventory consists of obtaining dendrometric variables and the georeferencing of each tree using a GPS device.

The details for defining the areas are presented in item 2.5 Flowchart Item 3: Analysis of obtained results.

\subsection{Flowchart Item 2A: TFP definition and implementation}

As previously mentioned, two plans were defined, the first of which (TFP) followed a systematic pattern, which is traditionally used by many companies in the planning and execution of infrastructures in the forest management area, including the company where the study was conducted.

This systematic planning consists of defining main roads, secondary roads, and equidistant storage yards. According to Figueiredo et al. (2007), optimal separation of main and secondary forest roads provides optimal skid distances, depending on machinery used, as storage yards are systematically distributed on forest roads (Figure 3).

Thus, the maximum logging distance corresponds to half of optimal road separation (Figueiredo et al., 2007), which is calculated by Equation (1) (FAO, 1974).

$\mathrm{SOE}=2 \sqrt{\frac{10 \mathrm{C}}{\mathrm{V} \cdot \mathrm{Tr}}}$

Wherein: SOE = optimal road separation distance, $\mathrm{C}=$ road construction cost per $\mathrm{km}, \mathrm{V}=$ exploitable volume per hectare, and $\mathrm{Tr}=$ skid cost per trail meter (round trip) per transported cubic meter.

The planning executed by the forest manager at UW-2 (the study area) is presented in Figure 3. In this planning, priority was given to building roads as straight as possible, with a distance of approximately $500 \mathrm{~m}$ between secondary roads, and a distance of approximately 250 $\mathrm{m}$ between yards.

\subsection{Flowchart Item $2 B$ : definition and implementation of OFP}

The planning for the second area was performed through mathematical programming. The model used was p-median, with restrictions 


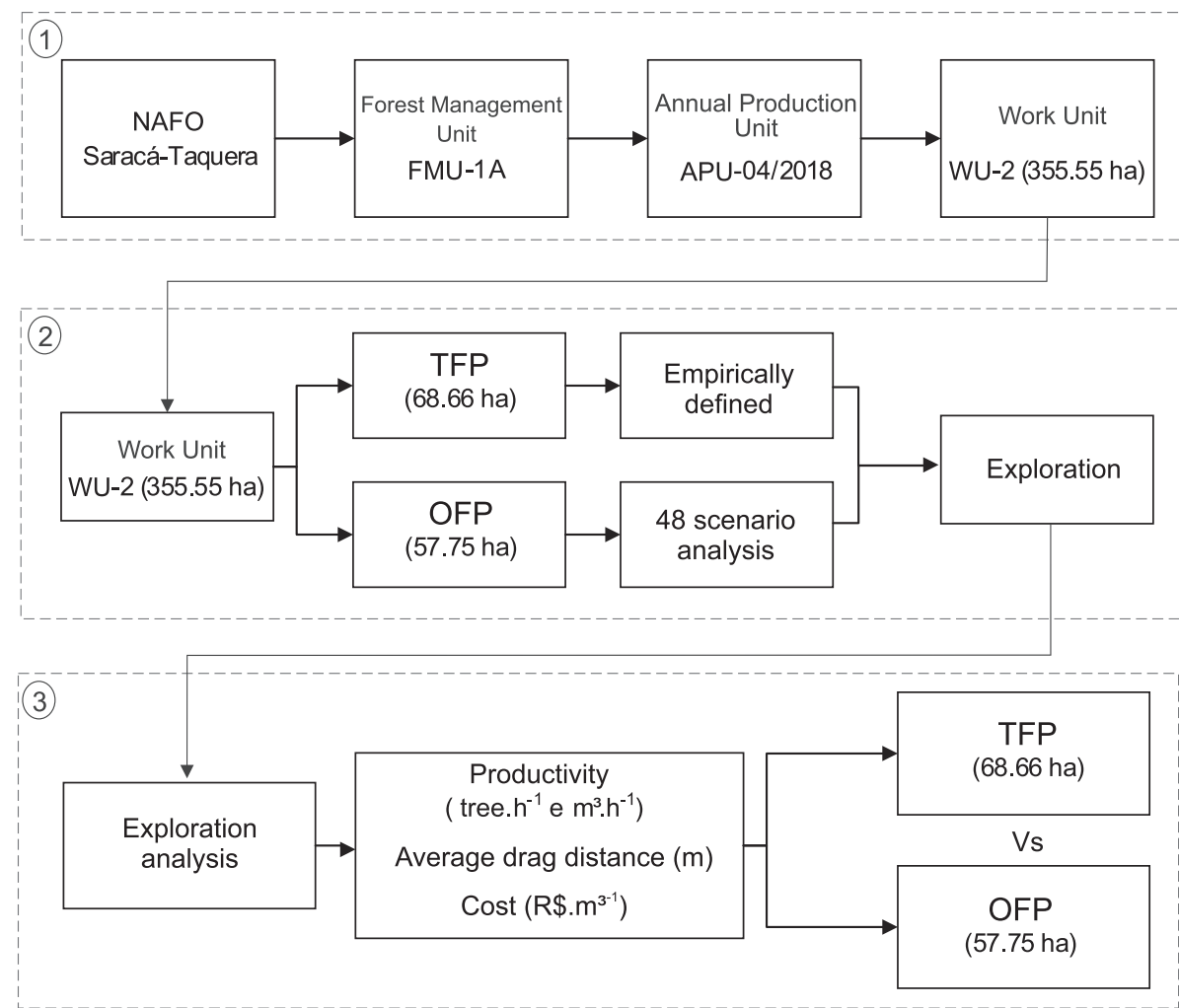

(1) Study area description

a) Definition of TFP planning and execution

(2) b) Definition of OFP planning and execution

(3) Analysis of the results obtained

Figure 1. Methodological flowchart of the steps performed in the study.

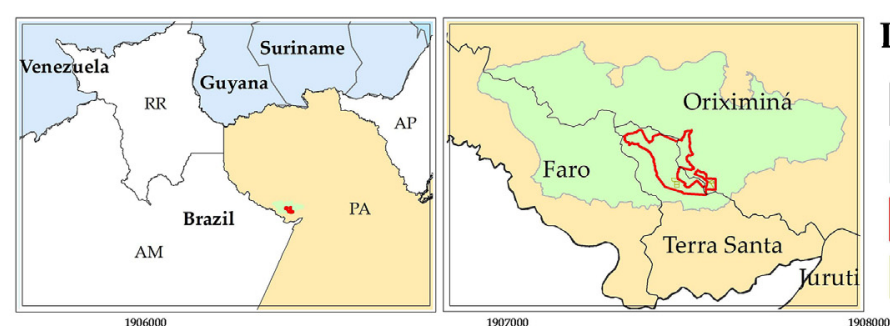

\section{Legend}

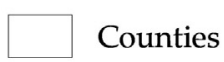

NAFO Saracá-Taquera

FMU - 1A

APU - 04/2018

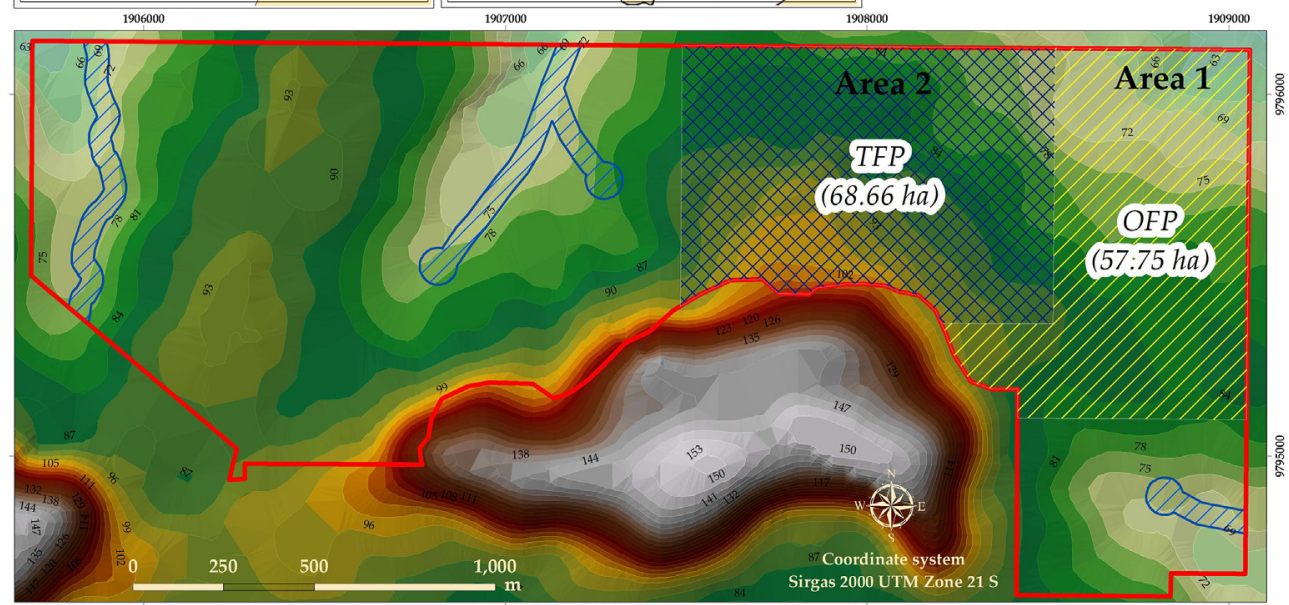

5 Work unit / WU-2 / 321.55 ha

Study area: APU-04/2018 - WU-2

OFP - 57.75 ha

PPA

$\times$ TFP - 68.66 ha

Figure 2. Location of the study area at NAFO Saracá-Taquera, APU-04/2018, WU-2, Oriximiná and Terra Santa, Pará, Brazil. 
Table 1

Variables analyzed for defining the study area.

\begin{tabular}{|c|c|c|c|c|c|c|c|}
\hline Planning & Area (ha) & $\mathrm{N}^{\circ}$ of yards & $\mathrm{N}^{\circ}$ of trees & Volume $\left(\mathrm{m}^{3}\right)$ & Total distance $(\mathrm{km})$ & Mean distance (m) & Mean max distance $(\mathrm{m})$ \\
\hline TFP & 68.66 & 6 & 379 & $1,739.89$ & 58.98 & 156 & 275 \\
\hline OFP & 57.75 & 5 & 355 & $1,337.67$ & 54.49 & 158 & 276 \\
\hline
\end{tabular}

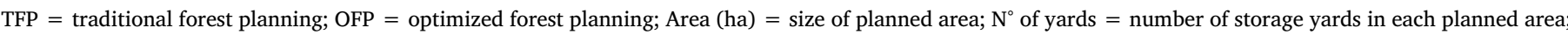

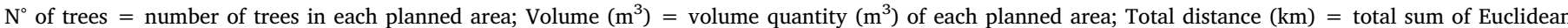

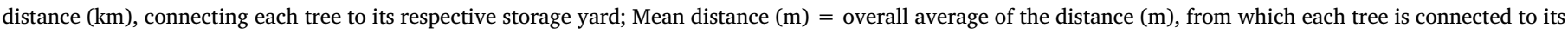
respective stockyard; Mean max distance $(\mathrm{m})=$ average distance $(\mathrm{m})$ of connecting the most distant trees to their respective storage yard.

of maximum volume capacity and maximum logging distance. Problem studies in this class seek to answer the following question: from a set of potential installations that are intended to serve certain customers, which ones should be selected to open by defining where the facility opens and which customers will be served by each facility selected? (Daneshzand and Shoeleh, 2009; Drezner and Hamacher, 2009; Fávero and Belfiore, 2013; Goldbarg and Luna, 2005; Klose and Drexl, 2005; Luenberger and Ye, 2016).

The mathematical model of p-median is described as follows, with maximum constraints of connections and capacities (Arenales et al., 2011; Daneshzand and Shoeleh, 2009; Daskin, 1995; Drezner and Hamacher, 2009; Eiselt and Marianov, 2011; Eiselt and Sandblom, 2004; Fávero and Belfiore, 2013; Goldbarg, 2015; Hurter and Martinich, 1989; Luenberger and Ye, 2016; Padberg and Rijal, 1996; Sule, 2001):

Minimize: $\sum_{i=1}^{n} \sum_{j=1}^{P} d_{i j} x_{i j}$

Subject to:

$\sum_{j=1}^{P} x_{i j}=1$

$\sum_{j=1}^{P} Y_{j}=p$

$x_{i j}-Y_{j} \leqslant 0$

$\sum_{i=1}^{n} q_{i} x_{i j} \leqslant Q_{j}$ $d_{i j} x_{i j} \leqslant \operatorname{Dmax}$

Wherein: $i=$ trees; $j=$ storage yards; $P=$ total number of yards that can be allocated; $d_{i j}=$ cost of connecting trees $i$ to yard $j ; p=$ number of yards to be effectively allocated $(p \in P) ; x_{i j}=$ binary variable ( 0 or 1 ) that takes the value 1 if tree $i$ is allocated in yard $j$, and 0 otherwise; $Y_{j}=$ binary variable $(0,1)$, assuming the value 1 if the yard is selected and zero otherwise; $q_{i}=$ tree volume $i, Q_{j}=$ maximum volume capacity supported by yard $j$; and $D \max =$ maximum connecting distance from tree $i$ to yard $j$.

The objective function (OF) (Equation (2)) minimizes the total cost of connecting each tree to each yard. The first constraint (Equation (3)) ensures that each tree cannot be linked to more than one yard. The second constraint (Equation (4)) ensures that of all possible yards (P) to be selected, only a certain yard number (p) will be selected. In practice, this restriction ensures that a small and predefined number of yards (p) is selected, that is, the selection of $\mathrm{p}$ within P. The third constraint (Equation (5)), associated with the second constraint (Equation (3)), helps decides which yard will be selected within P. The fourth constraint (Equation (6)) ensures that the maximum yard capacity (Qj) is not exceeded; and the constraint (Equation (7)) ensures that a tree $i$ is not bound to a yard $j$ beyond the maximum log skid distance (Dmax).

The database for processing was composed of trees defined to be felled together, as defined by the information obtained from the census forest inventory. A shapefile was made using geographic information system (GIS) software, which created a mesh of 685 equidistant points $30 \mathrm{~m}$ apart in the OFP study area, where each point represented a possible wood storage yard. The matrix of connection of each tree to each yard was calculated in software R, by Euclidean distance formula using tree coordinates and 685 possible yards. The relief of the study area was classified as flat. For this reason, no areas were restricted from the installation of infrastructure. Additionally no permanent

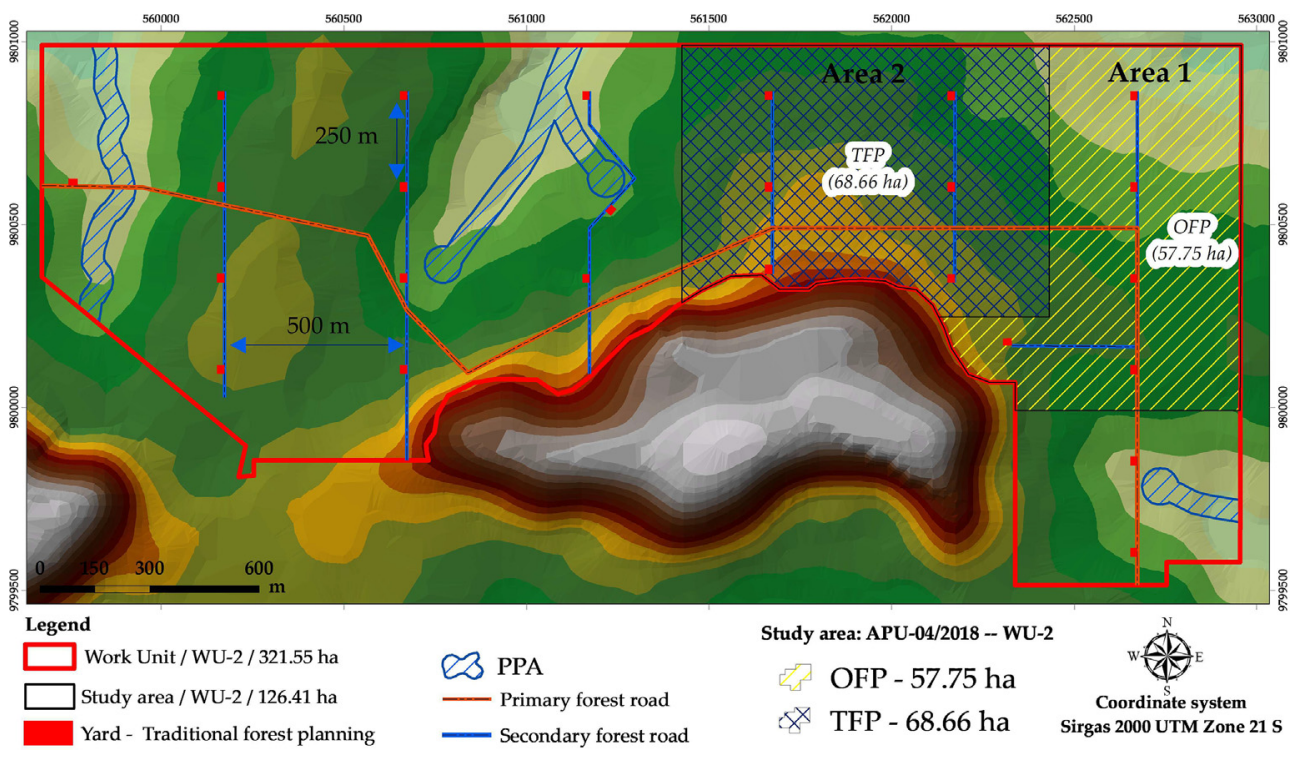

Figure 3. Traditional forest planning undertaken by forest manager in forest management area in the study area. 
preservation area (PPA), or any other type of restriction in the area, was present. If there had been any area restrictions, potential yards located within the restriction areas would have to be excluded, to prevent infrastructure allocation at an inappropriate location.

Utilizing the database, the problem was solved by exact method in CPLEX 12.7 ${ }^{\circledR}$ academic version software. Possible limits of constraints were set according to the decision maker responsible for the project in the company. A total of forty-eight scenarios were evaluated, representing combinations between the maximum logging distance (250, 300,350 , and $>350 \mathrm{~m}$ ), the storage yard capacity $(300,350,400$, and $>400 \mathrm{~m}^{3}$ ), and the number of storage yards (3, 4, and 5 yards). Based on the OF value and field layout of each scenario, the best feasible scenario to be implemented was defined. Subsequently, the access roads to the yards were defined, and maps for exploration of each storage yard were prepared.

During the planning of the forest road infrastructure, the shortest viable path and the straightest possible roads were prioritized. This planning was done manually, based on the experience of the decision maker. This procedure consists of creating a feature line file and later, connecting the yards already allocated as straight as possible and observing physical characteristics of the area such as relief, hydrography, and restricted areas. This procedure requires little effort from the decision-maker and does not affect the result of the proposed planning.

\subsection{Flowchart Item 3: analysis of obtained results}

To compare the performance of the planning methods, TFP and OFP, three relevant criteria were considered regarding tropical forest management: productivity, skidder movement within exploration area, and operation economic performance.

Logging activities were monitored to obtain productivity measures for 11 wood storage yards in the study area. Of these 11 yards, six were allocated according to TFP (Figure 3, Area 2) and five, according to OFP (Figure 3, Area 1). Thus, the size of the final area corresponded to the area whose trees belong to the respective yards in areas 1 and 2 .

The set of machines used for the extraction activity consisted of a Skidder 525 D Caterpillar grapple tractor and a 938 K Caterpillar loader. In addition, the entire logging operation was accompanied by a team that monitored volume measurement and log identification.

To calculate productivity, it was necessary to measure the effective time of logging activity. This time was calculated in hours, from the beginning to the end of activity, using a stopwatch. Eventual stops were also timed and deducted from the total activity time.

The harvested logs volume was calculated using the Smalian's formula (Machado, 2009). For this, diameter measurements were performed at the thinnest and thickest ends of each log, using a measuring tape, and the diameter was measured at the cutting face. The length of each log was also measured. To calculate the stockpiled volume in each yard, individual volumes of each $\log (\mathrm{Q} i)$, calculated by the Smalian method of logs stored in the respective yard, were summed.

The skid yield of each yard was obtained with Equation (8).

$P_{r}=\frac{\sum_{i=1}^{n} Q_{i}}{h e}$

Wherein: $P_{r}=$ skid operation productivity $\left(\mathrm{m}^{3} \cdot \mathrm{h}^{-1}\right.$ and trees. $\left.\mathrm{h}^{-1}\right)$; $Q_{i}=$ individual volume of $\log i\left(\mathrm{~m}^{3}\right)$; and $h e=$ effective working time per yard (hours).

To evaluate skidder movement within the exploration area, a Garmin 76 CSx global positioning system (GPS) device was employed, which was coupled to a skidder forestry tractor to monitor its path. After data collection, the information obtained by the GPS was transformed into a shapefile, which produced a map that represented the skidding path of trees from cutting site to storage yards.

A problem that occurs when using GPS is that, when moving continuously with a tractor, there may periodically be a signal loss that results in discontinuity of the route design. However, it is normal for a tractor to use the same skid track multiple times to skid different trees. Therefore, assuming that the GPS mapped path for the same track was repeated several times, manual identification was performed to identify the track most likely to be followed by the tractor. Thus, eliminating any discontinuity errors mentioned, by comparing all repetitions and correcting discontinuities.

From the information of trees that were skidded and the skidder forestry tractor route, it was possible to accurately quantify the individual tree-yard skid distance from each log, to the destination yard, in a GIS environment. Tree-yard distance is the distance traveled by the yard tractor to the tree. Therefore, the distance traveled by the tractor to tree and back to the yard represents the skid cycle.

To measure the economic performance in terms of operations cost, it was important to define which cost items to consider when comparing two planning methods. These cost items were restricted to the logging process. For this study, skid log activity was considered the log extraction process by the skidder forestry tractor. In this sense, once the logging activity and its respective cost items were defined, the company obtained the extraction cost of R $\$ 386.45 \mathrm{~h}^{-1}$ of skid logs activity.

Cost items, R\$ 386.45 per hour of skid activity, are the costs linked to the tractor and operations team. Assuming that the forest company hires a company to provide the service, they will be wanting to formulate a price that expresses the total cost of using the tractor per hour, regardless of which extraction process will be used (TFP or OFP). Based on this, the total cost of R\$ 386.45 per hour of skid activity was used as a reference for both TFP and OFP.

Thus, considering that the cost per hour of extraction was the same for both methods, a different criterion was necessary for comparing the economic performance of these analyzed planning methods. It was determined that a skid productivity measure would be used, that is, the skidded volume cost $\left(\mathrm{R} \$ . \mathrm{m}^{-3}\right)$. To arrive at this value for each of the two methods evaluated, the ratio between the total skid cost for each method was calculated by total volume drawn for each method according to Equation (9):

$D e_{i}=\frac{C T_{i}}{V T_{i}}$

Wherein: $D e_{i}=$ economic performance; $i=$ assessed planning $(i=$ TFP, OFP); $C T_{i}=$ total cost of planning $i$; and $V T_{i}=$ total volume of planning $i$.

The method that presented the lowest cost per cubic meter skidded was considered the most advantageous from an economic point of view.

\section{Results}

To clearly present the results, the findings are presented in two parts. The first part is dedicated to presenting the results related only to planning. Considering that two areas of study were defined (refer to Figure 2), it was decided to adopt the OFP plan for the first area (area 1) and the TFP plan for the second area (area 2).

Assuming that OFP was adopted in area 1, in section 3.1 we present the results comparing what would happen if hypothetically TFP had been adopted. This was analyzed in terms of forest roads and tree-yard Euclidean distance.

Considering that TFP was adopted in area 2 , section 3.2 presents the results comparing what would happen if hypothetically OFP had been adopted. This was also analyzed in terms of forest roads and tree-yard Euclidean distance.

The second part of results, section 3.3, is dedicated to comparing the execution of OFP and TFP applied to areas 1 and 2 .

\subsection{Comparison between TFP and OFP, in the area where OFP was implemented}

Initially in the study area, tree extraction planning was executed, 
which did not consider any optimization techniques (Figure 3). According to this original plan, extracting trees planned for felling and moving them to yards, would cover a total tree-yard Euclidean distance of $54.49 \mathrm{~km}$ (Table 1).

According to the methods previously described (Section 2) in this paper, this area did not follow the TFP method, but rather the OFP method. Thus, when analyzing the 48 proposed scenarios, considering $\mathrm{OF}$ value and the geographic location of yards, we selected the scenario that allocated five storage yards, with a maximum restriction volume of $350 \mathrm{~m}^{3}$, and a maximum skid distance restriction of $250 \mathrm{~m}$, as the best to be performed in this field.

By using OFP instead of TFP in this study area, the total Euclidean distance of tree-yard was reduced from $54.49 \mathrm{~km}$ to $43.47 \mathrm{~km}$. This reduction can be attributed to the optimization process, and corresponds to a $20.22 \%$ reduction. However, the number of forest roads in the TFP analysis was $1.47 \mathrm{~km}$ and in the OFP analysis was $1.70 \mathrm{~km}$, which is an increase of $13.66 \%$.

\subsection{Comparison between OFP and TFP, in the area where TFP was implemented}

As mentioned earlier, an initial tree harvesting plan was executed without considering any optimization techniques. As a comparison between the plans, a mathematical programming model used in the OFP area was replicated for the TFP area. According to the TFP plan, extracting trees planned for felling and moving them to yards would cover a total tree-yard Euclidean distance of $58.98 \mathrm{~km}$ (Table 1).

If the OFP method was used in the area where TFP was executed, the total tree-yard Euclidean distance would be reduced by $20.23 \%$ (11.93 $\mathrm{km}$ ). The number of roads in the TFP model was $2.03 \mathrm{~km}$ and in the OFP model was $2.00 \mathrm{~km}$, which was a reduction of $1.55 \%$.

\subsection{Comparison of execution between OFP and TFP}

Before starting comparisons between OFP and TFP in terms of execution, it is essential to mention that during execution, not all that was planned can be perfectly put into practice. This difference, which is normal to occur, is due to the unfeasibility of felling some trees for safety reasons or the fact that trunk does not have commercial quality (e.g., hollow, tortuous and/or pest-attacked stem).

When looking at Table 1 and Table 2, equivalent to the comparison of information from the planning phase (Table 1) and after execution (Table 2). The main highlight of this comparison was that, on average, there was a $29.56 \%$ reduction in number of trees planned for felling, for the abovementioned reasons.

Additionally, it is important to note that it would be impossible to apply OFP and TFP in the same area. Thus, for comparisons to be reliable, it was important for the areas to be as similar as possible. Figure 2 and Table 2 help verify that the studied areas (area 1 and 2) were similar in terms of area, flat relief, number of trees, and the average volume per tree.

Table 3 presents the variables analyzed during skidding activity at each yard for the type of planning. The average tree skidding productivity was 7.8 trees. $\mathrm{h}^{-1}$ and the coefficient of variation [CV (\%)] between yards was $12.39 \%$ for TFP. For OFP, it was 10.3 trees. $\mathrm{h}^{-1}$ and the CV was $6.79 \%$. Analyzing the productivity (average) of skidded wood, the TFP method obtained $35.78 \mathrm{~m}^{3} \cdot \mathrm{h}^{-1}$ and CV among yards of
$13.35 \%$ and the OFP method was $46.42 \mathrm{~m}^{3} \cdot \mathrm{h}^{-1}$ and CV of $8.42 \%$. In relative terms, the increase in OFP productivity compared to TFP was $32.05 \%$ (trees. $\mathrm{h}^{-1}$ ) and $29.74 \%\left(\mathrm{~m}^{3} \cdot \mathrm{h}^{-1}\right)$.

Evaluation of the total distance traveled per hour $\left(\mathrm{m} \cdot \mathrm{h}^{-1}\right)$ by the skidder tractor in both plans showed that on average the tractor traveled $2.66 \mathrm{~km} \cdot \mathrm{h}^{-1}$ and $2.78 \mathrm{~km} \cdot \mathrm{h}^{-1}$ for the TFP and OFP plan, respectively. Thus, a difference of $0.11 \mathrm{~km}$ was recorded between the plans.

Mean skid distance values are presented in Table 4. Only the treeyard distance was considered. This connection mean in TFP was 165.61 $\mathrm{m}$ and $\mathrm{CV}$ of $12.93 \%$ among yards; in OFP the mean was $137.20 \mathrm{~m}$ and CV of $11.44 \%$. In general, OFP provided a reduction of $17.16 \%$, approximately $56.82 \mathrm{~m}$ in each skid cycle.

Reliable execution of planned projects is an important factor in forest management areas. However, modifications can occur during execution for two main reasons: first is related to workforce qualification to execute the planning, and second is related to adversities encountered in field. In Figure 4, we observe the precision of the field exploration execution of TFP and OFP.

\section{Discussion}

\subsection{Comparison between TFP and OFP in areas 1 and 2}

Considering only the planning, the results found in items 3.1 and 3.2 show a similar trend, that is, OFP promoted a significant reduction in Euclidean distance of tree-yard when compared to TFP. This result was expected because in TFP, yards are allocated following systematic criterion that does not take into account the spatial distribution of trees in the forest. However, in OFP, the model that seeks to minimize tree-yard Euclidean distance, and this was explicitly evident.

It is important to note that the p-median problem is a Binary integer linear programming (BILP) problem, classified as NP-hard. In the present study, the reduced number of yards and trees to be explored in each area made it possible to obtain the solution by the exact method. This research did not consider solving problems with a large number of variables; therefore, it is not possible to state that it will be possible to find exact solutions to problems with a large number of variables. However, there is ample evidence from other studies that with the increase in the number of variables, there is an exponential increase in the number of possible combinations, which increases the difficulties in finding exact solutions and results in the need to use heuristic methods (Guastaroba and Speranza, 2014; Stefanello et al., 2015; Yaghini et al., 2013). Moreover, when it is not possible to obtain exact solutions for this type of problem in viable processing time, this is not a severe limitation since several heuristic methods can produce efficient solutions.

In contrast, for forest roads, the OFP method suggested construction of $13.66 \%$ more roads in Area 1 and $1.55 \%$ less roads in Area 2 . However, building $13.66 \%$ more road should be interpreted with caution. The first factor to be considered is that road building is more expensive because it requires soil tillage. From this point of view, building more roads is a negative result.

However, on a secondary road (open roads for log flow) it can be said that one linear meter of road corresponds to one linear meter of trail, as both have an average width of $4 \mathrm{~m}$. Thus, the results presented in items 3.1 and 3.2 indicate that the need for road construction in relation to the need for trail construction (at this time is hypothetically

Table 2

Quantitative comparison of two study areas.

\begin{tabular}{llllllll}
\hline Planning & Area (ha) & Skid time $(\mathrm{h})$ & $\mathrm{N}^{\circ}$ of yards & $\mathrm{N}^{\circ}$ of trees & Volume $\left(\mathrm{m}^{3}\right)$ & ${\text { Average }\left(\mathrm{m}^{3} \cdot \text { tree }^{-1}\right)}^{\text {Average yard area }(\text { ha) })^{*}}$ \\
\hline TFP & 68.66 & 32.50 & 6 & 248 & $1,119.06$ & 4.51 & 11.44 \\
OFP & 57.75 & 26.12 & 5 & 269 & $1,211.38$ & 4.50 & 11.55 \\
\hline
\end{tabular}

* Representation area of storage yard (Column 2 divided by Column 4 of this Table). 
Table 3

Variables analyzed during skidding activity for each study yard.

\begin{tabular}{|c|c|c|c|c|c|c|c|c|}
\hline Planning & Yard & Total time (h) & $\mathrm{N}^{\circ}$ of trees & Volume $\left(\mathrm{m}^{3}\right)$ & Total dist. $(\mathrm{km})$ & Mean dist. tree $^{-1}(\mathrm{~m})$ & Tree.h ${ }^{-1}$ & $\mathrm{~m}^{3} \cdot \mathrm{h}^{-1}$ \\
\hline \multirow[t]{6}{*}{ TFP } & 12 & 2.82 & 20 & 127.64 & 8.60 & 429.78 & 7.10 & 45.32 \\
\hline & 13 & 7.80 & 56 & 268.12 & 22.50 & 401.81 & 7.18 & 34.37 \\
\hline & 14 & 5.63 & 47 & 192.32 & 18.29 & 389.12 & 8.34 & 34.14 \\
\hline & 15 & 3.08 & 30 & 116.22 & 6.91 & 230.41 & 9.73 & 37.69 \\
\hline & 16 & 7.00 & 51 & 213.80 & 17.49 & 342.97 & 7.29 & 30.54 \\
\hline & 17 & 6.17 & 44 & 200.96 & 12.63 & 287.02 & 7.14 & 32.59 \\
\hline \multirow[t]{5}{*}{ OFP } & 19 & 5.60 & 55 & 226.22 & 16.87 & 306.71 & 9.82 & 40.40 \\
\hline & 20 & 5.80 & 67 & 300.41 & 16.57 & 247.36 & 11.55 & 51.80 \\
\hline & 21 & 4.75 & 49 & 209.02 & 13.33 & 271.95 & 10.32 & 44.00 \\
\hline & 22 & 6.73 & 64 & 318.82 & 17.53 & 273.86 & 9.50 & 47.35 \\
\hline & 23 & 3.23 & 34 & 156.91 & 8.40 & 246.97 & 10.52 & 48.53 \\
\hline
\end{tabular}

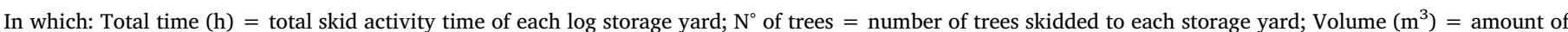

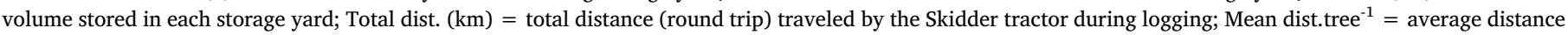
per tree; Tree. $h^{-1}=$ average yield of skidded trees; and $\mathrm{m}^{-3} \cdot \mathrm{h}^{-1}=$ average yield of skid volume.

Table 4

Total skid distance, number of cycles observed, and mean skid link distance values for each plan in the study area.

\begin{tabular}{lllll}
\hline Planning & Yard & $\begin{array}{l}\text { Total distance } \\
(\mathrm{km})\end{array}$ & $\begin{array}{l}\mathrm{N}^{\circ} \text { of skid } \\
\text { cycles }\end{array}$ & $\begin{array}{l}\text { Dist. tree-yard mean } \\
(\mathrm{m})\end{array}$ \\
\hline \multirow{2}{*}{ TFP } & 12 & 4.30 & 28 & 153.49 \\
& 13 & 10.00 & 54 & 185.19 \\
& 14 & 8.50 & 43 & 197.73 \\
& 15 & 3.11 & 21 & 148.18 \\
& 16 & 7.07 & 41 & 172.46 \\
OFP & 17 & 5.87 & 43 & 136.62 \\
& 19 & 7.39 & 46 & 160.55 \\
& 20 & 7.28 & 54 & 134.74 \\
& 21 & 6.56 & 44 & 149.12 \\
& 22 & 7.12 & 59 & 120.76 \\
& 23 & 3.38 & 28 & \\
\hline
\end{tabular}

represented by tree-yard Euclidean distance), in linear meters, in Areas 1 and 2, taking into account the OFP, it was 3.91\% and $4.25 \%$, respectively. Thus, the road totals, in linear meters, for areas 1 and 2 , correspond to $3.91 \%$ and $4.25 \%$ of the total trail paths, respectively. Thus, skid trails impacted a bigger area. Note that for Area 1 (item 3.1), in absolute terms, the OFP method suggested a $0.23 \mathrm{~km}$ increase in road construction: however, this increase provided a $11.02 \mathrm{~km}$ reduction in skid trails. In the case of Area 2, in addition to the OFP suggested reduction in road construction, a $12.93 \mathrm{~km}$ reduction in skid trails construction was also suggested.

Thus, concerning the TFP, the OFP caused a significant reduction in the distance from the drag trail, reducing the impacts caused to the forest. A plausible explanation for the better performance of the OFP is the fact that when using TFP, the yards are allocated systematically, disregarding the spatial distribution of the trees that will be felled and dragged. In the OFP, the spatial issue is taken into account in the model, that is, the decision is made with more information and analysis, which makes one think that the result found corroborates what is theoretically expected to happen.

In Silva et al. (2018a) a comparison was made between the results of the planning done in an optimized way and the traditional planning, obtaining a reduction in the infrastructure construction of the forest

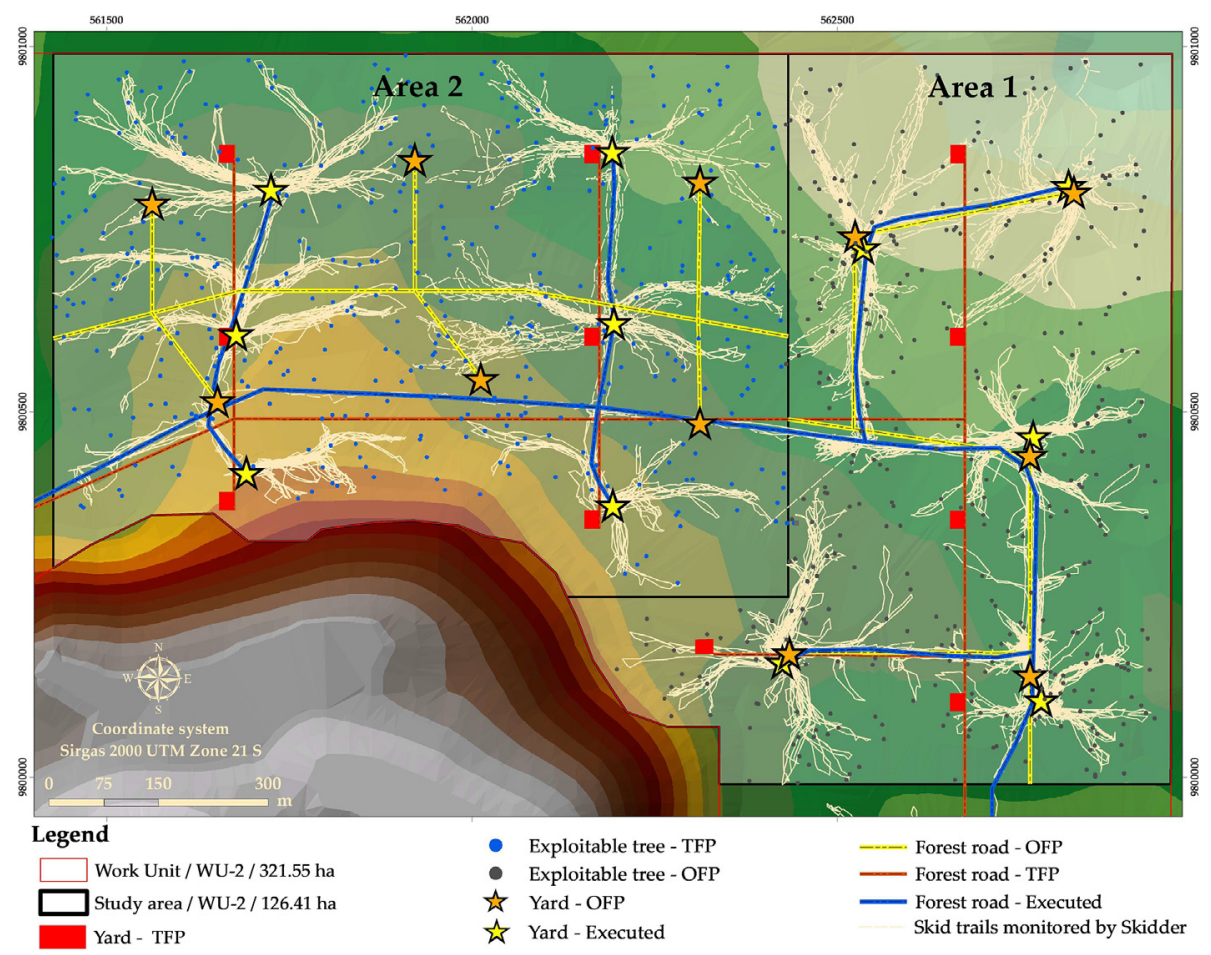

Figure 4. Infrastructure of forest roads, yards, and skid trails of planning and field execution in TFP and OFP study area. 
road, the wood storage yards and the skid trail, concluding to be advantageous the use of optimization models in planning. The same result was found in this work; that is, the use of optimization models was advantageous. However, in Silva et al. (2018a) it was not possible to validate the model's result; that is, the plans carried out by both the traditional and optimized methods were not executed, measured, and compared. On the other hand, in this work, in addition to assessing the optimization gains in the planning process, it was possible to verify that, in practical terms, that is, after the execution of traditional and optimized planning, the optimized process confirmed its superiority indicated at the level of planning. Similar results that corroborate the efficiency of an optimized exploration planning were found in the researches of Philippart et al. (2012); Sales et al. (2019) and Silva et al. (2018b)

\subsection{Comparison between OFP and TFP in the exploration execution}

Considering planning and execution, this study found an average difference of $29.56 \%$ (for both TFP and OFP methods), in terms of the number of trees selected for felling and those indeed harvested. This difference is strongly associated with forest inventory data provided by the company, which were data inputs to the models used in this work. The value of $29.56 \%$ could be much lower, indicating that an improvement in inventory methods will certainly contribute to the reduction between planned and executed processes, which is an optimization opportunity.

Forest inventory accuracy is essential to both the planning phase and the project execution phase because it is based on information from trees selected for the exploration, that the entire SFM infrastructure is planned. The OFP model considered the trees location to define the distances to a possible log storage yard. Thus, the accuracy of the positioning information became crucial, as the location can negatively affect planning performance.

However, when comparing the execution of planning for Areas 1 and 2 in terms of performance, it was initially important to remember the similarity between these areas, presented in item 3.3 Acknowledging this similarity, can assist in clearly evaluating, the performance of each method.

When analyzing the areas productivity, the better performance of OFP over TFP, that is, an increase of $32.66 \%$ in tree skid productivity and of volume by $29.74 \%$, was essentially due to the inherent empiricism of decisions taken at TFP. In the case of the OFP method, the decision involved much more analysis, with a yard allocation that considered a larger number of variables, so that each yard formed the best possible tree cluster, unlike TFP. Moreover, it was critical to this result that TFP did not take into account the spatial distribution of trees. In a native rainforest, this distribution is unpredictable and can vary significantly. By not considering this, there was a high likelihood that TFP would not select the best tree clusters to produce the best skid productivity.

Relative to the variation between the volume productivity for different yards, the results showed that the variation was greater for the TFP method. In other words, the volume productivity of the TFP method, in addition to being smaller than the volume productivity of the OFP method, presented more oscillation. This higher TFP swing was also strongly associated with the formation of tree clusters to be skidded for each yard. Because it did not take into account the spatial issue and used a systematic procedure for yards allocation, it was normal for the TFP plan to sometimes form clusters of a large number of trees close to each other. Additionally, clusters with a smaller number of trees that are more spaced from each other sometimes generate a greater variation in productivity. However, considering the spatial issue, the OFP plan tended to form more homogeneous clusters in terms of the number of trees, and the distance between them and the storage yard.

Analyzing the average distance traveled by the skidder forestry tractor per yard, $2.66 \mathrm{~km} . \mathrm{h}^{-1}$ in TFP and $2.78 \mathrm{~km} . \mathrm{h}^{-1}$ in OFP (Table 4), the average difference was $0.11 \mathrm{~km}$. This analysis corroborated the efficiency of the OFP method, because the average distance traveled was related to the displacement speed of the skidder forest tractor, which did not change. Thus, the higher yield of logs skidded by the OFP method (trees. $\mathrm{h}^{-1}$ and $\mathrm{m}^{3} \cdot \mathrm{h}^{-1}$ ) was attributed to the better positioning of the yards, and reflected by an increase in the number of skidding cycles per hour. That is, the skidder forestry tractor moved more strategically following the OFP method.

The distance traveled by the logs skidded was directly related to the yard's allocation, as the skidder tractor moved from the yard to the tree. Table 4 shows the average distance values as a function of the number of skid cycles analyzed during the study. The total distance comprised the sum of all tree-yard linked with the observed skid cycles. On average, the skid distance was reduced by $17.16 \%$ with the OFP plan. Considering the total logs skid distance of $86.42 \mathrm{~km}$ using the TFP method (Table 3), if the same area was planned with OFP, the reduction was estimated to be $14.83 \mathrm{~km}$. These absolute OFP reduction values were scalar, i.e., the larger the explored area, the greater the gain. Considering that the TFP explored area (68.66 ha) had an estimated log skid reduction of $14.83 \mathrm{~km}$, for the entire APU area - $2018(1,133.08$ ha) this reduction was estimated to potentially reach $244.72 \mathrm{~km}$.

Calculating the cost of cubic meter according to Equation 15 showed that the cost of cubic meter skidded using the TFP method was $\mathrm{R} \$ 11.22 \mathrm{~m}^{-3}$, and using the OFP method was $\mathrm{R} \$ 8.33 \mathrm{~m}^{-3}$. In relative terms, it represented a $25.76 \%$ cost reduction. Thus, it can be considered that for every $1,000 \mathrm{~m}^{3}$ skidded, adopting the OFP method would result in a savings of $\mathrm{R} \$ 2,890.27$.

In the research area studied, systematic planning was mainly favored for the areas of flat relief and a few areas of PPA. Among the six yards analyzed with TFP, there were yards producing a skid yield (trees. $\mathrm{h}^{-1}$ ) similar to OFP, as shown for yards 14 and 15 in Table 3. However, in more undulating areas and those with a greater presence of PPA, systematic planning tended to be less efficient.

The OFP method was superior to the TFP method, resulting in a more accurate yard allocation, where each yard formed the best possible tree cluster. Therefore, the OFP method was proved to be a robust tool for different forest types and terrain conditions, due to the possibility of easing constraints and analysis speed in different scenarios.

Finally, implementation of the OFP method did not interfere with exploration activities. This was an important fact that forestry companies consider when adopting new technologies. Using the OFP method did not change the dynamics of field activities, rather only the planning stage was changed. Companies tend to resist the use of new methodologies that promote significant changes in field activities. This is due to training costs and time spent learning the new technology.

\section{Conclusion}

Considering only the planning phase, the OFP method provided a significant reduction in the tree-yard Euclidean distance, without large variations in the planned amount of forest roads, as compared to the TFP method. Additionally, the execution of OFP provided an increase to the logs skid productivity. This was a result of more efficiently allocating the wood storage yards, as compared to the TFP method.

The implementation of OFP did not require change in routine of field activities or team training. This fact represented a positive point for the use of this methodology by forest companies. The OFP methodology proposed in this work can be used for the planning of forest exploitation systems.

Finally, it is essential to mention that the conclusions are taken in this work focus on the economic issue, not taking into account aspects related to environmental impacts, biodiversity, social issues, and other objectives that can be considered. However, it is important to say that the problem is very complex, and this research certainly needs to be continued with the collection of new data, new experiences and even adaptations in the model, such as, for example, the possibility of using 
models with multiple objectives related to mentioned variables.

\section{CRediT authorship contribution statement}

Evandro Ferreira Silva: Conceptualization, Methodology, Software, Validation, Formal analysis, Investigation, Writing - original draft, Writing - review \& editing. Gilson Fernandes Silva: Conceptualization, Methodology, Supervision, Project administration. Evandro Orfanó Figueiredo: Conceptualization, Methodology, Supervision. Adriano Ribeiro Mendonça: Conceptualization, Supervision. Cesar Junio Oliveira Santana: Conceptualization, Methodology. Nilton César Fiedler: Conceptualization, Methodology. Jeferson Pereira Martins Silva: Conceptualization, Writing - original draft, Writing - review \& editing, Visualization. Marcelo Otone Aguiar: Conceptualization, Writing - original draft, Writing - review \& editing, Visualization. Jeangelis Silva Santos: Conceptualization, Writing original draft, Writing - review \& editing, Visualization.

\section{Acknowledgments}

The authors thank the Federal University of Espírito Santo (UFES), Espírito Santo Research and Innovation Support Foundation (FAPES), National Council for Scientific and Technological Development (CNPq) and EBATA Forest Products for providing the necessary data for conducting this work.

\section{References}

Amaral, P., Veríssimo, A., Barreto, P., Vidal, E., 1998. Floresta para sempre: Um Manual para a Produção de Madeira na Amazônia. Pará, Imazon, Belém.

Arenales, M., Armentano, V., Morabito, R., Yanasse, H., 2011. Pesquisa operacional. Elsevier, Rio de janeiro.

Arima, E.Y., Walker, R.T., Perz, S.G., Caldas, M., 2005. Loggers and forest fragmentation: Behavioral models of road building in the Amazon basin. Ann. Assoc. Am. Geogr. https://doi.org/10.1111/j.1467-8306.2005.00473.x.

Arima, E.Y., Walker, R.T., Sales, M., Souza Jr., C., Perz, S.G., 2008. The Fragmentacion of in the Amazon Basin: Emergent Road Networks. Photogramm. Engineeering Remote Sens. 74, 699-709.

Bramucci, M., Seixas, F., 2002. Determinação e quantificação de fatores de influência sobre a produtividade de " harvesters" na colheita florestal. Sci. For. 62-74.

BRASIL, 2009. Resolução 406, de 02 de fevereiro de 2009. . Estabelece parâmetros técnicos a serem adotados na elaboração, apresentação, avaliação técnica e execução de Plano de Manejo Florestal Sustentável-PMFS com fins madeireiros, para florestas nativas e suas formas de sucessão no bioma Amazônia. Ministério.

BRASIL, 2006. Instrução Normativa 05, de 11 de dezembro de 2006. Dispõe sobre a Autorização Prévia à Análise Técnica de Plano de Manejo Florestal Sustentável-APAT, e dá outras providências. Ministério do. Meio Ambiente/IBAMA.

Braz, E.M., 2010. Subsídios para o planejamento do manejo de florestas tropicais da amazônia. 2010. 236 f. Tese (Doutorado em Engenheria Florestal) - Universidade Federal de Santa Maria, Santa Maria.

Braz, E.M., Carnieri, C., Arce, J.E., 2004. Um modelo otimizador para organização dos compartimentos de exploração em floresta tropical. Rev. Floresta 28, 77-83.

Braz, E.M., D'Oliveira, M.V.N., 1997. Planejamento de arraste mecanizado em floresta tropical. Rio Branco, AC, EMBRAPA, Instruções Técnicas.

Contreras, M., Chung, W., 2007. A computer approach to finding an optimal log landing location and analyzing influencing factors for ground-based timber harvesting. Can. J. For. Res. 37, 276-292. https://doi.org/10.1139/x06-219.

Daneshzand, F., Shoeleh, R., 2009. Facility Location, Contributions to Management Science. Physica-Verlag HD, Heidelberg. https://doi.org/10.1007/978-3-79082151-2.

Daskin, M.S., 1995. Network and Discrete Location. John Wiley \& Sons, Inc., Hoboken, NJ, USA. https://doi.org/10.1002/9781118032343.

Drezner, Z., Hamacher, H.W., 2009. Facility Location, Contributions to Management Science. Physica-Verlag HD, Heidelberg. https://doi.org/10.1007/978-3-79082151-2.

Eiselt, H. a, Marianov, V., 2011. Foundations of Location, International Series in Operations Research \& Management Science. Springer US, Boston, MA. https://doi. org/10.1007/978-1-4419-7572-0.

Eiselt, H.A., Sandblom, C.-L., 2004. Decision Analysis, Location Models, and Scheduling Problems. Springer, Berlin Heidelberg, Berlin, Heidelberg. https://doi.org/10.1007/ 978-3-540-24722-7.

FAO, 1974. logging and log transport in tropical high forest: a manual on production and costs. (FAO. fprest Series, 5, FAO. Forestry Development Paper,18), Roma.

Fávero, L.P., Belfiore, P., 2013. Pesquisa operacional para cursos de engenharia. Elsevier, Rio de janeiro.

Figueiredo, E.O., Braz, E.M., D’Oliveira, M.V.N., 2007. Manejo de precisão em florestas tropicais: Modelo digital de exploração florestal. EMBRAPA, Acre, Rio Branco, AC. Goldbarg, M.C., 2015. Programação Linear e Fluxos em Redes, 1st ed. Elsevier, Rio de janeiro.

Goldbarg, M.C., Luna, H.P.L., 2005. Otimização combinatória e programação linear: Modelos e Algoritmos, 2nd ed. Elsevier, Rio de janeiro.

Gomide, L.R., Moura, A.L. de M., Mello, J.M. de, 2011. Simulação otimizada da exploração florestal de impacto reduzido em uma mata nativa localizada em Lavras, MG. Universidade Federal de Lavras, Anais do XX congresso de pós-graduação da UFLA. Lavras, MG.

Guastaroba, G., Speranza, M.G., 2014. A heuristic for BILP problems: The Single Source Capacitated Facility Location Problem. Eur. J. Oper. Res. 238, 438-450. https://doi. org/10.1016/j.ejor.2014.04.007.

Hurter, A.P., Martinich, J.S., 1989. Facility Location and the Theory of Production. Springer, Netherlands, Dordrecht. https://doi.org/10.1007/978-94-009-2518-2.

IBAMA, 2007. Norma de execução n. ${ }^{\circ} 1$, de 24 abril de 2007. Institui, no âmbito desta Autarquia, as Diretrizes Técnicas para Elaboração dos Planos de Manejo Florestal Sustentável - PMFS. Instituto Brasileiro do meio Ambiente e dos Recursos Naturais Renovavéis -. IBAMA.

Issac Júnior, M.A., Gomide, L.R., Silva, P.H., Alves, J. de A., Figueiredo, E.O., 2014 Alocação de Pátios de armazenamento de madeira em um plano de manejo florestal na Amazônia ocidental. SBPO, Anais do XLVI Simpósio Brasileiro de Pesquisa Operacional. Salvador-BA.

Karlsson, J., Rönnqvist, M., Bergström, J., 2004. An optimization model for annual harvest planning. Can. J. For. Res. 34, 1747-1754. https://doi.org/10.1139/x04-043.

Kelley, J., Kuby, M., Sierra, R., 2013. Transportation network optimization for the movement of indigenous goods in Amazonian Ecuador. J. Transp. Geogr. 28, 89-100. https://doi.org/10.1016/j.jtrangeo.2012.11.006.

Klose, A., Drexl, A., 2005. Facility location models for distribution system design. European Journal of Operational Research. 4-29. https://doi.org/10.1016/j.ejor. 2003.10.031.

Lopes, M.S., 2018. Rotas multimodais para otimização da coleta de Castanha do Brasil e redistribuição espacial de colocações. 2018. 43 f. Tese (Mestre em Engenheria Florestal) - Universidade Federal de Viçosa, Viçosa.

Luenberger, D.G., Ye, Y., 2016. Linear and Nonlinear Programming, International Series in Operations Research \& Management Science. Springer International Publishing, Cham. https://doi.org/10.1007/978-3-319-18842-3.

Machado, M.P.O., 2013. Custo do manejo florestal madeireiro na Amazônia: um estudo de caso no Estado do Acre, 2012. 2013. 75 f. Monografia (Graduação em Engenehria Florestal) - Universidade Federal do Acre, Rio Branco.

Machado, S. do A., 2009. Dendrometria, $2^{\circ}$. ed. Unicentro, Guarapuava. https://doi.org/ 10.1126 /science. 24.624 .760 .

Martinhago, A.Z., 2012. Otimização para a locação de pátios de estocagem para exploração de impacto reduzido na amazônia brasileira. 2012. $236 \mathrm{f}$. Tese (Doutorado em Engenheria Florestal) - Universidade Federal de Lavras, Lavras.

Munaretti, A.M., 2016. Otimização do traçado de trilhas em áreas de manejo para produtos florestais não madereiros (PFNMs). 2016. $81 \mathrm{f}$. Dissertação (Mestrado em Ciência, Inovação e Tecnologia) - Universidade Federal do Acre, Rio Branco.

Murray, A.T., Snyder, S., 2000. Spatial Modeling in Forest Management and Natural Resource Planning. For. Sci. 46, 153-156. https://doi.org/10.1093/forestscience/46. 2.153.

Padberg, M., Rijal, M.P., 1996. Location, Scheduling, Design and Integer Programming, International Series in Operations Research \& Management Science. Springer, US, Boston, MA. https://doi.org/10.1007/978-1-4613-1379-3.

Philippart, J., Sun, M., Doucet, J., Lejeune, P., 2012. Mathematical formulation and exact solution for landing location problem in tropical forest selective logging, a case study in Southeast Cameroon. J. For. Econ. 18, 113-122. https://doi.org/10.1016/j.jfe. 2011.11.002

Sales, A., Gonzáles, D.G.E., Martins, T.G.V., Silva, G.C.C., Spletozer, A.G., Telles, L.A. de A., Siviero, M.A., Lorenzon, A.S., Sales, A., Gonzáles, D.G.E., Martins, T.G.V., Silva, G. C.C., Spletozer, A.G., Telles, L.A. de A., Siviero, M.A., Lorenzon, A.S., 2019. Optimization of Skid Trails and Log Yards on the Amazon Forest. Forests 10, 252 https://doi.org/10.3390/f10030252.

Shahi, S., Pulkki, R., 2013. Supply Chain Network Optimization of the Canadian Forest Products Industry: A Critical Review. Am. J. Ind. Bus. Manag. 03, 631. https://doi. org/10.4236/ajibm.2013.37073.

Silva, E.F., Silva, G.F., Figueiredo, E.O., Binoti, D.H.B., Mendonça, R.D.A., Torres, C.M.M.E., Pezzopane, J.E.M., 2018a. Allocation of Storage Yards in Management Plans in the Amazon by Means of Mathematical Programming. Forests 9, 127. https://doi.org/10.3390/f9030127.

Silva, P.H., Gomide, L.R., Figueiredo, E.O., Carvalho, L.M.T., Ferraz-Filho, A.C., 2018 b. Optimal selective logging regime and log landing location models: a case study in the Amazon forest. Acta Amaz 48, 18-27. https://doi.org/10.1590/1809 4392201603113

Sist, P., 2000. Les techniques d' exploitation à faible impact. Bois Forêst des Trop. 265, $31-40$.

Søvde, N.E., Løkketangen, A., Talbot, B., 2013. Applicability of the GRASP metaheuristic method in designing machine trail layout. Forest Sci. Technol. 9, 187-194. https:// doi.org/10.1080/21580103.2013.839279.

Stefanello, F., de Araújo, O.C.B., Müller, F.M., 2015. Matheuristics for the capacitated pmedian problem. Int. Trans. Oper. Res. 22, 149-167. https://doi.org/10.1111/itor. 12103.

Sule, D.R., 2001. Logistics Of Facility Location And Allocation, $1^{\circ}$. ed, Logistics of Facility Location and Allocation. Marcel Dekker, Inc., Ruston, Louisiana.

Walker, R., Arima, E.Y., Messina, J., Soares-Filho, B., Perz, S., Vergara, D., Sales, M., Pereira, R., Castro, W., 2013. Modeling spatial decisions with graph theory: logging roads and forest fragmentation in the Brazilian Amazon. Ecol. Appl. 23, 239-254. https://doi.org/10.1890/11-1800.1.

Yaghini, M., Karimi, M., Rahbar, M., 2013. A hybrid metaheuristic approach for the capacitated p-median problem. Appl. Soft Comput. 13, 3922-3930. https://doi.org/10. 1016/j.asoc.2013.04.009. 